\title{
岡山医学 会雑”誌
}

第99巻 5,6 合併号 （第1110,1111号）

昭和62年 6 月 30 日発行

\section{高脂肪食および高砂糖食のラット脂肪細胞における インスリン結合およびインスリン作用に およぼす影響}

岡山大学医学部第一内科学教室（主任：長島秀夫教授）

岡㟝悟

(昭和61年11月26日受稿)

Key words: 高脂肪食, 高砂糖食

脂肪細胞，インスリン結合

インスリン作用

緒言

生活様式の近代化に伴う糖尿病堌加の要因と して, 食生活の近代化における食物構成の高脂 肪, 高単純糖質, 低複合糖質, 低繊維化が疫学 的に指摘されている1)。このような食事性因子が 糖尿病発症に対しどのような影響をおよぼすか は必らずしも明らかではない。

この点に関して, 高脂肪食 ${ }^{2 \sim 6)}$ や高砂糖食 ${ }^{7,8)}$ で飼育したラットにおいて，主要なインスリン の標的細胞である脂肪細胞の受容体または受容 体以後の過程でインスリン作用が減弱するとい われている.しかしながら, 従来の研究では, 飼料中の脂肪あるいは砂糖, 果糖, ブドウ糖な
どの単純糖質が $60 ７ 0 \%$ （エネルギー比）含ま れた極めて極端な実験条件で行われているので, その成績を人の場合における食生活の近代化に 伴う食事組成の変化に対応して考えることはで きない.

著者は前報9）において，従来型の日本食をも デルとした低脂肪・無砂糖食（エネルギー比脂 肪 $10 \%$ ，澱粉 $70 \%$ ，砂糖 $0 \%$ ） と現代の西欧食 をモデルとした高脂肪・高砂糖食（脂肪 $40 \%$ ， 澱粉 $20 \%$ ，砂糖20\%）を用いたラットの飼育実 験結果から, 高脂肪・高砂糖食に糖尿病発症促 淮効果があることを報告した.

そこで本研究は，上記のような高脂肪・高砂 糖食が糖尿病発症を促進する機序を解明するた 
め，ラットの算離脂肪細胞を用い，インスリン 結合，3-0-メチルグルコース (以下 3OMG) 摂 取およびグルコース酸化を測定し，脂肪細胞に おけるインスリン作用について検討した.

\section{方法}

\section{1. 実験動物および飼料}

生後 6 週路（体重約70 g）の雄性 SpragueDawley 系ラットを 4 群に分け, 前報で用いた 飼料の組成と同様の低脂肪・無砂糖食（エネル ギー比で脂肪，湟粉，砂糖が $10,70,0 \%$ ：以 下 $C$ 群)，低脂肪·高砂糖食 $(10,50,20 \%$ ：以 下 CS 群)，高脂肪 - 無砂糖食 $(40,40,0 \%$ ： 以下 $\mathrm{F}$ 群) および高脂肪・高砂糖食 $(40,20$, $20 \%$ ：以下 FS 群）の各飼料を投与し, 飼料と 水を自由に摄取させた。

\section{2. 遊離脂肪細胞の調整}

各飼料で 8 週間飼育後, ラットを摂食状態の まま断頭屠殺し，ただちに副䔂丸脂肪組織を採 取し, Rodbell ${ }^{10)} の$ 方法に準じ遊離脂肪細胞を 得た。各実験時, Hirsch 5 ${ }^{11)}$ の方法に準じ遊 離脂肪細胞をオスミウム酸固定し，その数と平 均直径を算定した.

3. ${ }^{125} \mathrm{I}$ ーインスリンの結合

Foley 5 ${ }^{12)}$ の方法に準じ，遊離脂肪細胞（約 $5 \times 10^{5}$ 個) ${ }^{125} \mathrm{I}$ ーインスリン (New England Nuclear 社) $0.5 \mathrm{ng} / \mathrm{ml}$, 種々の濃度の非標識 ンスリン (porcine crystalline insulin, Sigma 社), bacitracin ( $0.5 \mathrm{~g} / \mathrm{l}$, Sigma 社) と $2 \%$ 牛血 清アルブミン（以下 BSA : Fraction V, Amour 社)を含む Krebs Ringer Bicarbonate (以下 KRB)-Hepes 緩衝液 (pH 7.4) 中で $37^{\circ} \mathrm{C}, 45$ 分 間振擝孵置後, $10^{\circ} \mathrm{C}$ の $0.9 \% \mathrm{NaCl}$ 液 $10 \mathrm{ml}$ を 加えて反応を止め，その上に dinonylphythalate $1.2 \mathrm{ml}$ を重疊し， $1000 \times \mathrm{g}$ で 40 秒間遠沈後，浮遊 した脂肪細胞塊を採取し，結合した ${ }^{125}[$ ーインス リンをガンマーカウンターにて測定した。なお，

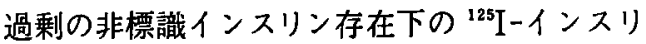
ン結合を非特異的結合として差し引いた。

4. 3-0-メチルグルコース摂取

Whitesell 5 ${ }^{13)} の$ 方法に準じインスリン剌激 下の 3OMG 摂取を測定した. $4 \%$ BSA-KRBHepes 緩衝液 (pH7.4)でリポクリット $40 \%$ に調
整した遊離脂肪細胞をインスリン $(40 \mathrm{ng} / \mathrm{ml})$ と $24^{\circ} \mathrm{C}$ で 1 時間前孵置後，その $40 \mu 1$ をとり，あ らかじめ 3OMG (0.1 mM), ${ }^{14} \mathrm{C}-3 \mathrm{OMG}(0.1 \mu \mathrm{Ci}$, New England Nuclear 社) を含む KRB-Hepes 緩衝液 (pH 7.4)を入れたミニバイアル(Nunch 社)に移した，20秒および60分間稃置後, phloretin (0.1 mM) を含む KRB-Hepes 緩衝液 $(\mathrm{pH} 7.4)$ $400 \mu 1$ にて反応を停止させ，ただちに dinonyl-

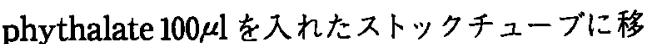
し, $2000 \times \mathrm{g}$ で40秒間遠沈後，浮遊した脂肪細胞 塊を採取し，摂取された ${ }^{14} \mathrm{C}-3 \mathrm{OMG}$ を液体シンチ レーションカウンターにて測定した。 なお，あらかじ めphloretin を加光た反応液中へ脂肪細胞を添加 し，ただちに遠沈分離後液体シンチレーションカ ウンターにて測定した值をブランクとした。

5. グルコース酸化

Gliemann ${ }^{14)}$ の方法に準じ，遊離脂肪細胞（約 $1.5 \times 10^{5}$ 個) をグルコース $(0.25 \mathrm{M}), 1{ }^{14} \mathrm{C}-$ グル コース $(0.2 \mu \mathrm{Ci})$ を含む $4 \% \mathrm{BSA}-\mathrm{KRB}-\mathrm{Hepes}$ 緩衝液 (pH7.4) 中にて, インスリン添加 ( $40 \mathrm{ng}$ ) $\mathrm{ml})$ または非添加の条件下で $37^{\circ} \mathrm{C} ， 2$ 時間振晹 那置し， $8 \mathrm{~N}$ 硫酸にて反応を停止させた後，産 生された ${ }^{14} \mathrm{CO}_{2}$ を採集し，液体シンテレーショ ンカウンターにて測定した。

成績

\section{1. 実験動物}

飼育期間中, FS 群は他の群に比し㩒取エネ ルギー量および体重增加量が多い傾向があった。 飼育 8 週後の体重, および副睪丸脂肪重量と遊 離脂肪細胞の平均直径を Table 1 に示した. 体 重はFS 群が他の 3 群に比し有意 $(\mathrm{p}<0.05)$ に 重く，C，CS，F 群間には差がなかった．副幸丸脂 肪重量は，FS 群が C および $\mathrm{F}$ 群に比し $(\mathrm{p}<$ 0.01)，また CS 群が C 群に比し $(\mathrm{p}<0.05)$, 有 意な增加がるられたが， C, F 群間には差がなか った。また，脂肪細胞の平均直径は，C群に比 し他の 3 群で有意 $(\mathrm{p}<0.05)$ に大きかったが, CS, F, FS 群間には有意な差がなかった。

2. ${ }^{125} I$ イインスリン結合

各群における遊離脂肪細胞のインスリン結合 を Fig. 1 に示した. 非標識インスリンの各濃度 下における ${ }^{125}[$ ーインスリン結合は 4 群間に差が 
なく，また，これらの Scatchard 解析において

も 4 群間に有意な差がみられなかった。

3. 3-0-メチルグルコースの搷取

各群における遊離脂肪細胞の $30 \mathrm{OMG}$ 摂取量を

Fig. 2 に示した. インスリン $40 \mathrm{ng} / \mathrm{ml}$ と前餒置 後の単位脂肪細胞当りの $30 \mathrm{OMG}$ 摂取量は C 群 $0.47 \pm 0.21$ (nM/10 $\mathrm{cells} / 10 \mathrm{sec}$ ), CS 群 $0.42 \pm$ $0.19, \mathrm{~F}$ 群 $0.46 \pm 0.18, \mathrm{FS}$ 群 $0.36 \pm 0.15$ で,

FS 群がやや低い傾向がみられたが，4群間に
有意な差はなかった。

4.グルコース酸化

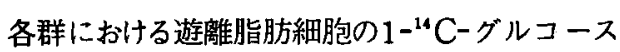
酸化の成績を Fig. 3 に示した. インスリン非添

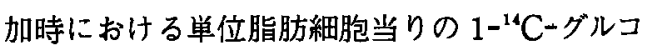
一ス酸化は, C 群 $91.9 \pm 22.4$ (nM/10 cells $/ \mathrm{hr}$.), $\mathrm{CS}$ 群 73.4 $\pm 24.7, \mathrm{~F}$ 群 $60.0 \pm 45.1, \mathrm{FS}$ 群 72.7 \pm 37.0 で，4 群間に有意な差がみられなかった。 一方, インスリン $40 \mathrm{ng} / \mathrm{ml}$ 存在下の 1 - "“C-グル

Table 1 Body Weight, Epididymal Fat Pad and Mean Fat Cell Size

\begin{tabular}{|c|c|c|c|c|}
\hline & (n) & $\begin{array}{c}\text { Body Weight } \\
\text { (g) }\end{array}$ & $\begin{array}{c}\text { Epididymal } \\
\text { Fat Pad } \\
(\mathrm{g} / 100 \mathrm{gBW})\end{array}$ & $\begin{array}{l}\text { Mean Fat } \\
\text { Cell Size } \\
\quad(\mu \mathrm{m})\end{array}$ \\
\hline $\begin{array}{c}\text { Low Fat Diet } \\
\text { No Sugar } \\
\text { High Sugar }\end{array}$ & $\begin{array}{l}5 \\
5\end{array}$ & $\begin{array}{l}429.0 \pm 19.3 \\
437.8 \pm 10.4\end{array}$ & $\begin{array}{l}1.77 \pm 0.42 \\
2.19 \pm 0.27^{\star} \mathrm{b}\end{array}$ & $\begin{array}{l}87.2 \pm 2.9 \\
92.5 \pm 5.2^{\star_{b}}\end{array}$ \\
\hline $\begin{array}{c}\text { High Fat Diet } \\
\text { No Sugar } \\
\text { High Sugar }\end{array}$ & $\begin{array}{l}5 \\
5\end{array}$ & $\begin{array}{l}435.4 \pm 14.6 \\
453.6 \pm 11.5^{* a}\end{array}$ & $\begin{array}{l}1.97 \pm 0.23 \\
2.47 \pm 0.27 * *_{c}\end{array}$ & $\begin{array}{l}95 \cdot 5 \pm 7 \cdot 1^{\star} \mathrm{b} \\
97 \cdot 5 \pm 6.8^{\star 2} \mathrm{tb}\end{array}$ \\
\hline $\begin{aligned} \text { Mean fat cell } \\
\text { with } 2 \% \text { osmium } \\
* \mathrm{p}<0.05, * * \mathrm{p}<0 \\
\\
\mathrm{a} \\
\mathrm{b} \\
\mathrm{c}\end{aligned}$ & $\begin{array}{l}\text { ize w } \\
\text { tetro } \\
.01 \\
\text { vs ot } \\
\text { vs Lo } \\
\text { vs Lo }\end{array}$ & $\begin{array}{l}\text { as measured after } \\
\text { cide in saline. } \\
\text { Fat No Sugar Di } \\
\text { Fat No Sugar an }\end{array}$ & isolated fat & $\begin{array}{l}\text { Is were fixed } \\
(\mathrm{M} \pm S D)\end{array}$ \\
\hline
\end{tabular}

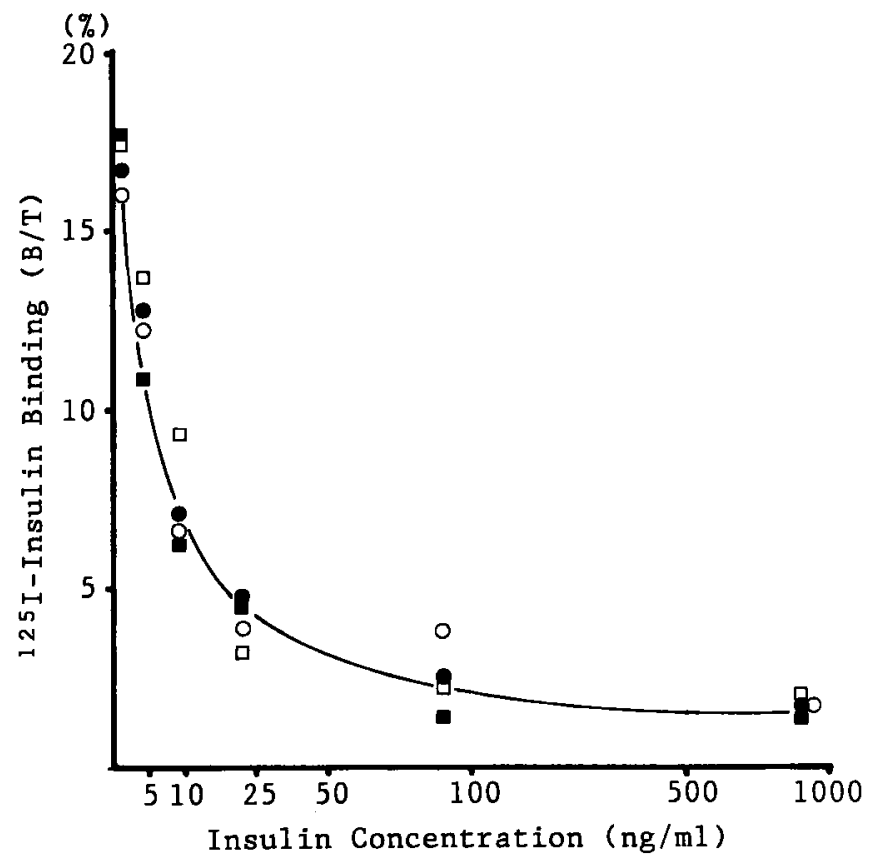

Fig. $1{ }^{125}$ I-insulin binding to isolated rat adipocytes. Adipocytes from low fat-no sugar (O), low fat-high sugar $(\bullet)$, high fat-no sugar $(\square)$ and high fathigh sugar ( $\square$ ) diet fed rats were incubated with ${ }^{125}$ I-insulin in the presence of various concentrations of unlabelled insulin. 


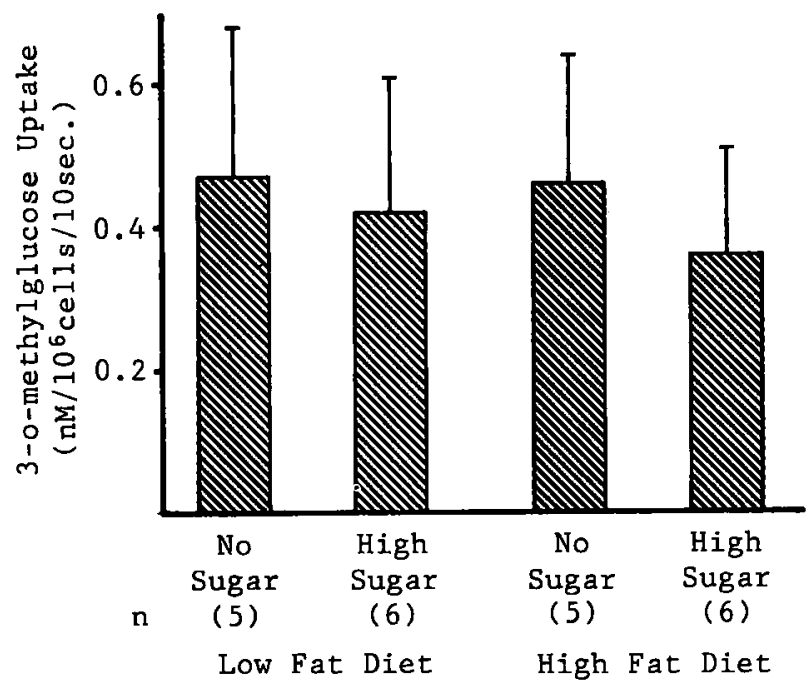

Fig. 2 Insulin $(40 \mathrm{ng} / \mathrm{ml})$-stimulated 3o-methylglucose uptake by isolated rat adipocytes.

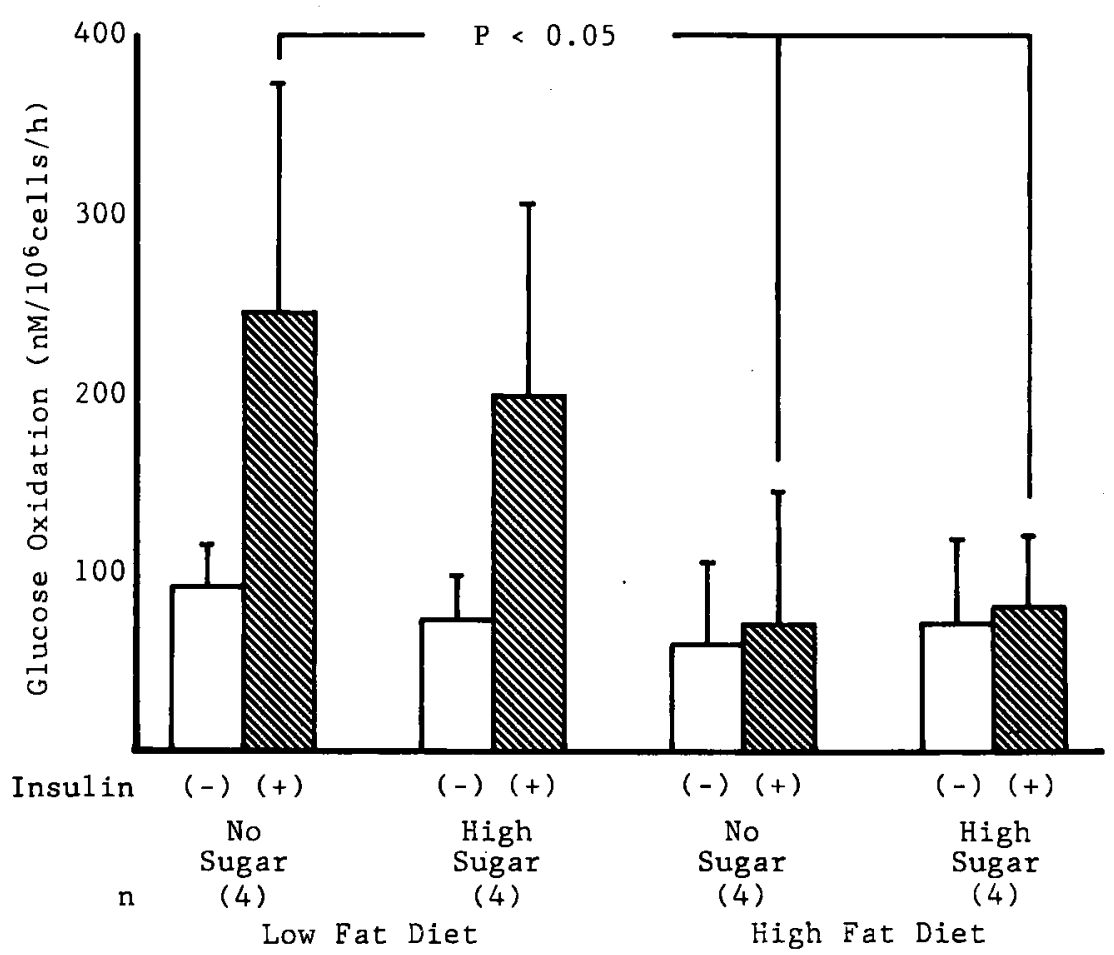

Fig. 3 Basal and insulin ( $40 \mathrm{ng} / \mathrm{ml}$ )-stimulated glucose oxidation by isolated rat adipocytes.

コース酸化は, C 群 $248.9 \pm 125.2, \mathrm{CS}$ 群 197.2 $\pm 110.4, \mathrm{~F}$ 群 76.1 $\pm 68.4, \mathrm{FS}$ 群 $80.4 \pm 30.6$ で あり，Fおよび FS 群はC 群に比し有意に低值 であったが，C，CS 群間およびF, FS 群間には 有意な差がみられなかった、インスリン存在下
のグルコース酸化をインスリン非存在下のそれに 対する増加率でみると，C 群 299.9土44.1（\%), CS 群 274.4 $\pm 50.3, \mathrm{~F}$ 群 $137.8 \pm 9.6, \mathrm{FS}$ 群 126.1 \pm 19.1 となり，F，FS 群はC，CS 群に比し著明 な低值であったが，C，CS 群間およびF，FS 群 
間には有意な差がみられなかった。

\section{考案}

前報9)で報告したように,ラットにおいて現 代型西欧食の食事組成である高脂肪・高砂糖食 飼育により，日本の在来型食事組成である低脂 肪 - 無砂糖食飼育に比し, 明らかな耐糖能低下 と高インスリン血症, およびインスリン負荷時 の感受性低下がみとめられ，インスリン抵抗性 が招来されると考えられた，一方，高脂肪食ま たは高砂糖食単独飼育でも同様の酎糖能低下， 高インスリン血症がみられたが，外来インスリ ンに対する感受性は高砂糖食飼育で明らかな低 下がみられたのに対し，高脂肪食飼育では低脂 肪食飼育と差がみられなかったことから, 高脂 肪食飼育と高砂糖食飼育によるインスリン抵抗 性発現機序は異なることが推定された。

本実験の結果, 各飼料群間に遊離脂肪細胞の インスリン結合および $30 M G$ 蛽取は有意な差が みられなかったことから，高脂肪食や高砂糖食 飼育の脂肪細胞におけるインスリン受容体およ び糖の取り込みに対する影響はみられないこと が示された。しかしながら，1-19C-グルコース の酸化は F, FS 群が C, CS 群に比し有意に低 下したことから, 高脂肪食飼育により脂肪細胞 におけるインスリン受容体以後の過程で糖利用 が低下することが明らかであったが，CS 群は C 群と有意な差がなく, 高砂糖食は脂肪細胞に おけるインスリン作用に影響をおよぼさないこ とが示された。

このことは, in vivoにおいて，高砂糖食飼育 でインスリン感受性低下がみられ，一方, 高脂 肪食飼育ではみられなかった前報の成績と矛盾 するが, in vivoの場合, 脂肪組織以外のインス リン標的組織におけるインスリン感受性も考虑 に入れる必要がある。この点に関して，Tobey ら ラットの筋肉と肝の灌流を行い, 通常飼料で飼 育したラットと比較し，インスリンによる筋肉 のグルコース摄取には差がなかったが，肝のグ ルコース放出に対するインスリンの抑制効果が 有意に低下していることを示し，フラクトース 飼育のインスリン感受性におよぼす影響は標的
組織により異なることを示唆している.

ところで, 脂肪細胞のインスリン感受性は脂 肪細胞の大きさと関係があり，大きな細胞は小 さな細胞に比しインスリン感受性が低いとされ

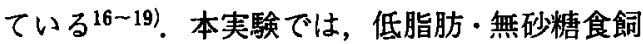
育群に比し, 高脂肪 - 無砂糖食, 高脂肪・高砂 糖食飼育群の脂肪細胞は有意に大きかったこと から，高脂肪食による脂肪細胞の肥大がインス リン感受性低下の一因となることも推定される. しかしながら，低脂肪・高砂糖食飼育群でも低 脂肪 - 無砂糖食飼育群に比し脂肪細胞の平均直 径が有意に大きかったが，インスリン作用には 差がなかったことから，脂肪細胞の大きさとイ ンスリン感受性との間には直接の関係はないも のと考えられる.

また，高脂肪食の脂肪細胞におけるインスリ ン作用におよぼす影響について, Ip ら²), Olefsky $5^{4)}$, 岩本 ${ }^{20}$ はインスリン結合の低下（受容体数 の減少）とそれに伴う糖の透過および利用の低 下を示し，一方 Lavau $5^{5}$, Salans $5^{6)}$ はイン スリン結合の低下を伴わない糖の㩒取，利用の 低下を報告しており，必ずしも意見の一致をみ ていない．本実験では，高脂肪食飼育により脂 肪細胞のインスリン結合および糖の摂取には著 変がなかったが，糖酸化に著明な低下がみられ たことから，高脂肪食は受容体以後の過程でイ ンスリン作用を減弱させると考えられた。

\section{結論}

食生活の近代化と糖尿病増加との関係を実験 的に解明するため, 日本の在来型食事内容をモ デルとした低脂肪・無砂糖食，現代の西欧食を モデルとした高脂肪・高砂糖食，および低脂肪 - 高砂糖食, 高脂肪・無砂糖食の各飼料で, 8 週間飼育したラットの副睪丸脂肪組織より脂肪

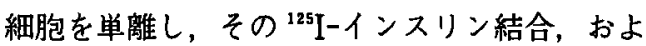
び3-0-メチルグルコース摂取とグルコース酸化 を測定し，脂肪細胞におけるインスリン作用に ついて検討した。

その結果，高脂肪・高砂糖食飼育ラットでは 低脂肪 - 無砂糖食ラットに比し, 副睪丸脂肪重 量の増加, 脂肪細胞直径の増大がみられた。単 離脂肪細胞において,インスリン結合には差が 
なくまたインスリン刺激下のメチルグルコー 又摂取にも差が見られなかったが、グルコース 酸化には著明な低下がみとめられた。したがっ て, 高脂肪・高砂糖食飼育により, 脂肪細胞の 肥大がみられたが，インスリン受容体には変化 がなく, 受容体以後の過程，とくに糖酸化過程 でインスリン作用の減弱が招来されると考えら れた。

高脂肪食または高砂糖食単独の影響について 検討した結果, 高脂肪・無砂糖食飼育では, 高 脂肪・高砂糖食飼育と同様, 糖酸化の著明な低 下がみられたが，糖摂取およびインスリン結合 には影響がみられなかった。一方，低脂肪・高 砂糖食飼育では, 低脂肪・無砂糖食飼育に比し， 副睪丸脂肪量の増加, 脂肪細胞径の增大がみら れたにもかかわらず, 単離脂肪細胞のインスリ ン結合，およびインスリン作用には有意な差が みられなかった。したがって，脂肪細胞におい ては高砂糖食飼育の影響がみられず，in vivoで みられた高砂糖食飼育によるインスリン感受性 低下，耐糖能低下には脂肪組織以外のインスリ ン標的組織が関与すると推定された。

以上，脂肪細胞を用いた本実験結果から，現 代の西欧型食事内容の高脂肪・高砂糖食は脂肪 細胞の肥大，すなわち肥満を招来し，脂肪細胞 における受容体以後のインスリン作用を減弱さ せ，糖尿病発症を促進すると考えられる。

本論文の要旨は第26回日本糖尿病学会総会におい て発表した.

稿を終わるにあたり, 御指導, 御校閲を賜った岡 山大学医学部第一内科学教室, 長島秀夫教授ならび に岡山大学保健管理センター, 山吹隆宽教授に深謝 いたします。

献

1. West KM : Epidemiology of diabetes and its vascular lesions ; Chapter 7. in Factors Associated with Occurrence of Diabetes. Elsevier, New York (1978) 191-284.

2. Blazquetz $E$ and Quijada $C L$ : The effect of a high fat diet on glucose, insulin sensitivity and plasma insulin in rats. $\mathrm{J}$ Endocrinol (1968) 42, 489-494.

3. Ip C, Tepperman HM, Holohan $P$ and Tepperman $J$ : Insulin binding and insulin response of adipocytes from rats adapted to fat feeding. J Lipid Res (1976) 17, 588-599.

4. Olefsky JM and Saekow M : The effects of dietary carbohydrate content on insulin binding and glucose metabolism by isolated rat adipocytes. Endocrinology (1978) 103, 2252-2263.

5. Lavau M, Fried SK, Susini $C$ and Freychet $P$ : Mechanism of insulin resistance in adipocytes of rats fed a high fat diet. J Lipid Res (1979) 20, 8-16.

6. Salans LB, Foley JE, Wardzala LJ and Cushman SW : Effects of dietary composition on glucose metabolism in rat adipose cells. Am J Physiol (1981) 240, E175-E 183.

7. Vrana $A$ and Kazdova $L$ : Insulin sensitivity of rat adipose tissue and of diaphragm in vitro: Effect of the type of dietary carbohydrate (starch-sucrose). Life Sci (1970) 9, 257-265.

8. Zavaroni I, Sander S, Scott S and Reaven GM : Effect of fructose feeding on insulin secretion and insulin action in the rat. Metabolism (1980) 29, 970-973.

9. 岡㟝 悟：高脂肪食および高砂糖食のラット耐糖能，インスリン反応およびインスリン感受性におよぼ す影響．岡山医学会雑誌（1987） 99，337-344。

10. Rodbell M : Metabolism of isolated fat cells. I. Effect of hormones on glucose metabolism and lipolysis. J Biol Chem (1964) 239, 375-380.

11. Hirsch $J$ and Gallian $\mathrm{E}$ : Methods for the determination of adipose cell size in man and animals. J Lipid Res (1968) 9, 110-119. 
12. Foley JE, Laursen $\mathrm{A}$, Sonne $\mathrm{D}$ and Gliemann $\mathrm{J}$ : Insulin binding and hexose transport in rat adipocytes. Diabetologia (1980) 19, 234-241.

13. Whitesell RR and Gliemann $\mathrm{J}$ : Kinetic parameters of transport of 3-o-methylglucose in adipocytes. J Biol Chem (1979) 254, 5276-5283.

14. Gliemann $\mathrm{J}$ : Assay of insulin-like activity by the isolated fat cell method. I. Factors influencing the response to crystalline insulin. Diabetologia (1967) 3, 382-388.

15. Tobey TA, Mondon CE, Zavaroni I and Reaven GM : Mechanism of insulin resistance in fructosefed rats. Metabolism (1982) 31, 608-612.

16. Livingston JN and Lockwood DH : Direct measurements of sugar uptake in small and large adipocytes from young and adult rats. Biochem Biophys Res Commun (1974) 61, 989-996.

17. Olefsky J M : The effects of spontaneous obesity on insulin binding, glucose transport, and glucose oxidation of isolated rat adipocytes. J Clin Invest (1976) 57, 842-851.

18. Czech MP : Cellular basis of insulin insensitivity in large rat adipocytes. J Clin Invest (1976) 57, $1523-1532$.

19. Hissin P J, Foley JE, Wardzala L J, Karneli E, Simpson I A, Salans LB and Cushman S W : Mechanism of insulin-resistant glucose transport activity in the enlarged adipose cell of the aged, obese rats. Relative depletion of intracellular glucose transport systems. J Clin Invest (1982) $70,780-790$.

20. 岩本安彦：ラット脂肪細胞のインスリン受容体，グルコース摂取，グルコース酸化におよぼす高脂肪食の 影響. 糖尿病 (1984) 27, 497-505. 
Effect of high fat and high sugar diet on insulin binding

and insulin action in isolated rat adipocytes

\title{
Satoru OKAZAKI
}

The First Department of Internal Medicine, Okayama University Medical School

\author{
(Director : Prof. H. Nagashima)
}

To clarify on a cellular basis the mechanism of the diabetogenic effect of the westernized diet, insulin binding, insulin stimulated 3-0-methylglucose uptake and glucose oxidation were studied in isolated adipocytes from rats fed experimental diets : low fat-no sugar diet (energy ratio of $10 \%$ fat, $\mathbf{7 0 \%}$ starch, a model of the traditional Japanese diet), high fathigh sugar diet $(40 \%$ fat, $20 \%$ starch, $20 \%$ sugar, a model of the westernized diet), low fat-high sugar diet (10\% fat, $50 \%$ starch, $20 \%$ sugar) and high fat-no sugar diet (40\% fat, $\mathbf{4 0 \%}$ starch).

In high fat-high sugar diet rats, epididymal fat and mean fat cell size were significantly greater than in low fat-no sugar diet rats. There was no significant difference in insulin binding and insulin stimulated 3-0-methylglucose uptake between high fat-high sugar diet rats and low fat-no sugar diet rats. However, insulin stimulated glucose oxidation was markedly lower in high fat-high sugar diet rats. Therefore, it is suggested that the high fat-high sugar diet induced a post-receptor defect but did not influence receptor binding in rat adipocytes.

In high fat-no sugar diet rats, a similar post-receptor defect was found, but in low fat-high sugar diet rats, insulin binding and post-receptor insulin action were unchanged.

In conclusion, the high fat-high sugar diet may produce diabetogenic effects through reduced insulin action due to a postreceptor defect. 